\title{
Reboxetine Enhances the Olanzapine-Induced Antipsychotic-Like Effect, Cortical Dopamine Outflow and NMDA Receptor-Mediated Transmission
}

\author{
Monica M Marcus', Kent Jardemark', Anna Malmerfelt', Carl Björkholm' and Torgny H Svensson*,' \\ 'Section of Neuropsychopharmacology, Department of Physiology and Pharmacology, Karolinska Institutet, Stockholm, Sweden
}

\begin{abstract}
Preclinical data have shown that addition of the selective norepinephrine transporter (NET) inhibitor reboxetine increases the antipsychotic-like effect of the $D_{2 / 3}$ antagonist raclopride and, in parallel, enhances cortical dopamine output. Subsequent clinical results suggested that adding reboxetine to stable treatments with various antipsychotic drugs (APDs) may improve positive, negative and depressive symptoms in schizophrenia. In this study, we investigated in rats the effects of adding reboxetine to the second-generation APD olanzapine on: (i) antipsychotic efficacy, using the conditioned avoidance response (CAR) test, (ii) extrapyramidal side effect (EPS) liability, using a catalepsy test, (iii) dopamine efflux in the medial prefrontal cortex and the nucleus accumbens, using in vivo microdialysis in freely moving animals and (iv) cortical N-methyl-D-aspartate (NMDA) receptor-mediated transmission, using intracellular electrophysiological recording in vitro. Reboxetine $(6 \mathrm{mg} / \mathrm{kg})$ enhanced the suppression of CAR induced by a suboptimal dose $(1.25 \mathrm{mg} / \mathrm{kg})$, but not an optimal $(2.5 \mathrm{mg} / \mathrm{kg})$ dose of olanzapine without any concomitant catalepsy. Addition of reboxetine to the low dose of olanzapine also markedly increased cortical dopamine outflow and facilitated prefrontal NMDA receptor-mediated transmission. Our data suggest that adjunctive treatment with a NET inhibitor may enhance the therapeutic effect of low-dose olanzapine in schizophrenia without increasing EPS liability and add an antidepressant action, thus in principle allowing for a dose reduction of olanzapine with a concomitant reduction of dose-related side effects, such as EPS and weight gain.

Neuropsychopharmacology (2010) 35, 1952-1961; doi:I0.1038/npp.2010.69; published online 12 May 2010
\end{abstract}

Keywords: noradrenaline transporter; antipsychotic; antidepressant; dopamine; glutamate; schizophrenia

\section{INTRODUCTION}

Previous studies have shown the critical importance of optimal dopamine transmission in the prefrontal cortex for certain aspects of cognition, such as working memory, and indicate that dysfunctional dopamine $\mathrm{D}_{1}$ receptors may contribute to cognitive impairments in schizophrenia (see Abi-Dargham et al, 2002; Goldman-Rakic et al, 2004; AbiDargham and Moore, 2003). Moreover, glutamate, the excitatory transmitter in cortical pyramidal cells, is involved in higher mental functions, such as cognition, memory and learning, and a glutamatergic synaptic hypofunction in schizophrenia seems indicated (see Coyle et al, 2003), a notion recently supported by the demonstration of a reduced prefrontal expression of the $\mathrm{N}$-methyl-D-aspartate (NMDA) receptor subunits NR1, NR2A and NR2C in

*Correspondence: Professor T Svensson, Department of Physiology and Pharmacology, Karolinska Institutet, Nanna Svartz väg 2, Stockholm, S I7I 77, Sweden, Tel: +46852 487 921, Fax: 468308 424, E-mail: torgny.svensson@ki.se

Received 24 November 2009; revised 12 March 2010; accepted 6 April 2010 schizophrenic patients (Beneyto and Meador-Woodruff, 2008). In addition, several other transmitter systems are in all probability involved in the control of cognitive functions (see Briand et al, 2007), as well as in the pathophysiology of schizophrenia, such as the catecholaminergic systems, because elevation of central noradrenergic and secondarily dopaminergic activity, for example, by administration of $\alpha_{2}$-adenoreceptor antagonists, has been shown to improve working memory, as well as attention, learning and memory in rodents (Lapiz and Morilak, 2006; Sara and Devauges, 1989).

Clozapine, the prototypical atypical antipsychotic drug (APD), has been found to be superior to first (FGAs) and other second-generation APDs (SGAs) in treatment-resistant schizophrenia (see Swartz et al, 2008; Kane et al, 1988; Lewis et al, 2006; McEvoy et al, 2006; Taylor and DuncanMcConnell, 2000), as well as in reducing suicidality in schizoaffective disorders and schizophrenia (see Hennen and Baldessarini, 2005; Meltzer et al, 2003). Thus, the clinical efficacy of clozapine seems superior to both FGAs and most, if not all SGAs (Davis et al, 2003; Leucht et al, 2009). Unfortunately, the use of clozapine has been associated with a risk of agranulocytosis, which limits its 
use. Besides its relatively low affinity for the dopamine $D_{2}$ receptor, clozapine possesses high affinity for a variety of other receptors, and several serotonergic receptors, for example, $5-\mathrm{HT}_{2 \mathrm{~A} / \mathrm{C}}, 5-\mathrm{HT}_{1 \mathrm{~A}}, 5-\mathrm{HT}_{6}$, as well as $\alpha_{2}$-adrenoceptors have been suggested to contribute to its superior efficacy (see, eg, Meltzer and Huang, 2008; Svensson, 2003a; Marcus et al, 2005). The SGA olanzapine is structurally similar to clozapine and shows higher affinity for several serotonergic receptors than for the $\mathrm{D}_{2}$ receptor (Schotte et al, 1996). However, although clozapine possesses a high affinity for $\alpha_{2}$-adrenoceptors, olanzapine has a low affinity for these receptors (Shahid et al, 2009). Both clozapine and olanzapine elevate cortical dopamine and norepinephrine outflow to a greater extent than FGAs such as haloperidol (Devoto and Flore, 2006; Li et al, 1998; Moghaddam and Bunney, 1990; Nomikos et al, 1994; Westerink et al, 1998). In contrast to FGAs, both clozapine and olanzapine also markedly facilitate cortical NMDA receptor-mediated transmission (Jardemark et al, 2002; Ninan et al, 2003), an effect that may contribute to improve negative symptoms and cognitive dysfunction in schizophrenia (see eg Stone et al, 2007).

The antidepressant drug reboxetine, a selective norepinephrine reuptake inhibitor (NRI), has been claimed to improve drive and motivation, as well as social and cognitive functioning in depressed patients (Ferguson et al, 2003; Kasper, 1999; Montgomery, 1997; Schatzberg, 2000). A cognitive-enhancing effect of the selective NRI atomoxetine has also been observed in healthy volunteers (Chamberlain et al, 2006). In rodents, addition of reboxetine to the $\mathrm{D}_{2 / 3}$ antagonist raclopride has been shown to significantly enhance the antipsychotic-like effect of the FGA raclopride without increasing its extrapyramidal side effect (EPS) liability, as well as to markedly increase cortical dopamine output (Linner et al, 2002). Moreover, reboxetine has recently been found to enhance the effect of raclopride also on cortical NMDA receptor-mediated transmission (Jardemark et al, unpublished observation). Thus, preclinical results suggest that concomitant norepinephrine transporter (NET) inhibition may provide means to augment the efficacy of FGAs in schizophrenia.

In this study, we have examined in rats whether concomitant NET inhibition by means of reboxetine might enhance the efficacy of olanzapine, and potentially mimic some of the preclinical effects of clozapine. The antipsychotic effect was assessed by using the conditioned avoidance response (CAR) paradigm, a preclinical test with high predictive validity for clinical antipsychotic effect (Arnt, 1982; Wadenberg and Hicks, 1999). EPS liability was examined by using a catalepsy test. Dopamine outflow in the medial prefrontal cortex (mPFC) and the nucleus accumbens (NAC) was measured by in vivo microdialysis in freely moving animals. Finally, the effects on cortical NMDA receptormediated transmission were examined using intracellular electrophysiological recording in pyramidal cells in vitro.

\section{MATERIALS AND METHODS}

\section{Animals}

Adult male Wistar rats ( $\sim 250 \mathrm{~g}$ on arrival) were used for behavioral and microdialysis experiments, whereas male
Sprague-Dawley rats ( $\sim 70 \mathrm{~g}$ on arrival; B\&K Universal, Sollentuna, Sweden) were used for in vitro electrophysiological experiments. The animals were housed under standard laboratory conditions with a temperature of $21^{\circ} \mathrm{C}$ and relative humidity of $55-65 \%$, with food (R34, Ewos, Södertälje, Sweden) and water ad libitum. For the behavioral tests, the animals were kept on a reversed $12 / 12 \mathrm{~h}$ light/dark cycle (lights off at $0600 \mathrm{~h}$ ), whereas for the other experiments, animals were maintained on a $12 / 12 \mathrm{~h}$ light/ dark cycle (lights on at $0600 \mathrm{~h}$ ). The animals were acclimatized for at least 5 days before experiments. Experiments were approved by, and conducted in accordance with, the local animal ethics committee, Stockholm North and the Karolinska Institutet, Sweden.

\section{CAR Behavior}

The CAR methodology used has previously been described in detail (Linner et al, 2002; see Wadenberg and Hicks, 1999). In brief, rats were trained and tested in conventional shuttle boxes $(530 \times 250 \times 225 \mathrm{~mm})$, divided into two compartments of equal size by a partition with an opening (Salmi et al, 1994). On presentation of the $80 \mathrm{~dB}$ white noise (Lafayette Instruments, Lafayette, IN) conditioned stimulus (CS), the rats had $10 \mathrm{~s}$ to move from one compartment of the shuttle box into the other. If the rat remained in the same compartment for more than $10 \mathrm{~s}$, an intermittent electric shock (intershock interval $2.5 \mathrm{~s}$, shock duration $0.5 \mathrm{~s}$ ) of $\sim 0.4 \mathrm{~mA}$, that is, the unconditioned stimulus (UCS), was presented to the grid floor until an escape was performed. If the rat did not respond within $50 \mathrm{~s}$, the trial was terminated, that is, escape failure. The position of the rat was automatically transferred to the computer and avoidance (response to CS within 10s), escape (response to CS + UCS), escape failure (failure to respond within $50 \mathrm{~s}$ ) and intertrial crosses were recorded. The animals were trained for 5 days, each session consisted of $\sim 20$ trials randomly distributed over $15 \mathrm{~min}$. Only animals reliably performing $>85 \%$ avoidance were included in the study. Experiments were preceded by a pretest and experiment sessions, lasting $10 \mathrm{~min}$, were conducted at 20, 90 and $240 \mathrm{~min}$ after last injection. Experimental days were separated by at least two non-experimental days. The animals were tested in a counterbalanced change-over design serving as their own controls (Li, 1964).

\section{Catalepsy Measurements}

Catalepsy measurements were performed in a dimly lit room at 30, 90 and 120 min after drug administration (see, eg, Linner et al, 2002). The rat was placed on an inclined grid $\left(60^{\circ}\right)$ and allowed $30 \mathrm{~s}$ of adaptation before observations started. These were performed for a maximum of $2.5 \mathrm{~min}$ and the time until the rat initiated a movement by one of its paws was recorded. Catalepsy was scored from 0 to 5 , according to the time (square root transformation) the rat remained immobile $(\mathrm{min}): 0=0.00-0.08$; $1=0.09-0.35 ; \quad 2=0.36-0.80 ; \quad 3=0.81-1.42 ; \quad 4=1.43-2.24$; $5 \geqslant 2.25$ (Ahlenius and Hillegaart, 1986). The different treatments were blinded to the observer. 


\section{In Vivo Microdialysis}

Our procedures for microdialysis have previously been described (Frånberg et al, 2008). In brief, rats were anesthetized with a cocktail of Hypnorm $(0.315 \mathrm{mg} / \mathrm{ml}$ fentanyl citrate and $10 \mathrm{mg} / \mathrm{ml}$ fluanisone; Janssen-Cilag, Saunderton, UK) and Dormicum (5 mg/ml midazolam; Roche $A B$, Stockholm, Sweden) diluted in distilled water $(1: 1: 2 ; 5 \mathrm{ml} / \mathrm{kg}$, intraperitoneal (i.p.)) mounted in a stereotaxic frame, and implanted with dialysis probes in the mPFC or NAC (anteroposterior $(\mathrm{mm})$ : +3.2 , + 1.6; mediolateral: $-0.6,-1.4$; dorsoventral: $-5.2,-8.2)$, respectively, relative to bregma and dural surface (Paxinos and Watson, 1998). Dialysis occurred through a semi-permeable membrane (Filtral AN69, Hospal Industrie, Meyzieu, France) with an active surface length of $4 \mathrm{~mm}$ (mPFC) or $2 \mathrm{~mm}$ (NAC). Dialysis experiments were conducted $\sim 48 \mathrm{~h}$ after surgery in awake freely moving rats. The dialysis probe was perfused with a physiological perfusion solution (in mM: $147 \mathrm{NaCl}, 3.0 \mathrm{KCl}, 1.3 \mathrm{CaCl}_{2}, 1.0 \mathrm{MgCl}_{2}, 1.0 \mathrm{NaHPO}_{4}$, $\mathrm{pH} 7.4$ ) at a rate of $2.5 \mu \mathrm{l} / \mathrm{min}$, set by a microinfusion pump (Harvard Apparatus, Holliston, MA). Dialysate samples were collected over 30 (mPFC) or $15 \mathrm{~min}$ (NAC). Online quantification of dopamine was accomplished by highperformance liquid chromatography (HPLC) coupled to electrochemical detection (ESA Bioscience, Chelsford, MA), with a detection limit of $\sim 0.2 \mathrm{fmol} / \mathrm{min}$. The injector (Valco Instruments, Houston, TX) were directed by a computerized system, Totalcrom WS version 6.3 (Perkin Elmer, Wellesley, MA). Separation of dopamine and metabolites was achieved by reversed phase liquid chromatography. The mobile phase consisted of $55 \mathrm{mM}$ sodium acetate buffer ( $\mathrm{pH} 4.0$ ), $12 \%$ methanol and $0.55 \mathrm{mM}$ octanesulfonic acid and delivered by an HPLC pump (Model 2150, Pharmacia LKB, Sweden) on a C-18 column (Nucleocil 150/ $75 \times 4.6 \mathrm{~mm}, 5 \mu \mathrm{m})$, flow rate $0.8 \mathrm{ml} / \mathrm{min}$. After separation, the analysate was passed through a guard cell with an applied oxidizing potential of $50 \mathrm{mV}$ to reduce baseline. Samples were quantified by sequential oxidation and reduction in a high-sensitive analytical cell (model 5011; ESA Bioscience) that was controlled by a potentiostat (Coulochem II model 5200; ESA Bioscience) with applied potentials of $400 \mathrm{mV}$ and $-200 \mathrm{mV}$ for detection of metabolites and dopamine, respectively. Injection of drug was performed after a stable outflow ( $<10 \%$ variation) of dopamine and metabolites. Baseline was calculated as the average of the last two (mPFC) or four (NAC) pre-injection values. The placement of the probe was later verified under microscope in slices stained with neutral red.

\section{In Vitro Electrophysiological Experiments}

Our procedures for electrophysiological experiments have previously been described (Konradsson et al, 2006). Briefly, the rats were decapitated while under halothane anesthesia (AstraZeneca AB, Södertälje, Sweden). The brains were quickly removed and cooled in ice-cold Ringer's solution (in mM: $126 \mathrm{NaCl}, 2.5 \mathrm{KCl}, 2.4 \mathrm{CaCl}_{2}, 1.3 \mathrm{MgCl}_{2}, 1.2$ $\mathrm{NaH}_{2} \mathrm{PO}_{4}, 10$ D-glucose, $18 \mathrm{NaHCO}_{3}, \mathrm{pH} 7.4$ ) aerated by $95 \%$ $\mathrm{O}_{2}: 5 \% \mathrm{CO}_{2}$. The brains were cut coronally into $450 \mu \mathrm{m}$ slices, using a Vibroslice (Campden model MA 752, World Precision Instruments, FL), and kept submerged in aerated
Ringer's solution at room temperature for $>1 \mathrm{~h}$ to allow for recovery. A slice containing $\mathrm{mPFC}$ (approximately anterioposterior $+3.2 \mathrm{~mm}$ from bregma) was transferred to a recording chamber $\left(32{ }^{\circ} \mathrm{C}\right)$, and held submerged between two nylon nets. The chamber was continuously perfused with aerated Ringer's solution, flow rate $1.5-2.5 \mathrm{ml} / \mathrm{min}$. Electrodes were pulled from borosilicate glass capillaries (i.d. $0.58 \mathrm{~mm}$; Clark Electromedical Instruments, Pangbourne, UK) by using a horizontal electrode puller (Model P-87, Sutter Instruments, San Rafael, CA). Recording electrodes were filled with $2 \mathrm{M} \mathrm{KAc} \mathrm{(55-120} \mathrm{M \Omega ),} \mathrm{and}$ used for recording with an Axoclamp 2A amplifier (Molecular Devices, CA). Penetrations of cells by sharp electrodes were performed blindly. The electrophysiological criteria for distinguishing presumed pyramidal from nonpyramidal neurons have been described previously (Arvanov et al, 1997; Connors and Gutnick, 1990). It is very rare to impale fast-spiking interneurons with a relatively low resistance microelectrode (McCormick et al, 1985), which might account for not recording fast-spiking non-pyramidal cells. The presumed pyramidal cells of the mPFC have relatively long spike duration (1-3 ms at half-maximum spike amplitude) and show a pronounced spike-frequency adaptation in response to constant-current depolarization pulses. Single electrode voltage-clamp (holding potential $-60 \mathrm{mV}$ ) was performed in the discontinuous mode with a sampling rate of $5-6.2 \mathrm{kHz}$. The voltage-clamp recordings were acquired using digital/analogue sampling and acquisition software (Clampex version 9.2, Molecular Devices). During the voltage-clamp recordings of NMDA $(10-15 \mu \mathrm{M})$ evoked currents, tetrodotoxin $(0.5 \mu \mathrm{M}$, to block the action potentials), glycine ( $1 \mu \mathrm{M}$, to enhance the NMDA-induced responses) and bicuculline $\left(5 \mu \mathrm{M}\right.$, to block the $\mathrm{GABA}_{\mathrm{A}}$ responses) were included in the Ringer's solution. All drugs used were diluted in Ringer's solution and administered through bath perfusion. The amplitude of the NMDAinduced current after drug or drug combinations was divided by the amplitude of the control NMDA-induced current for calculation of drug effect on prefrontal NMDA transmission.

\section{Statistical Analysis}

The data from the behavioral experiments are not normally distributed and accordingly non-parametric tests were used. Thus, for the CAR data, that is, avoidance behavior and intertrial crosses, we used the Friedman two-way analysis of variance (ANOVA) followed by Wilcoxon matched-pairs signed-ranks test, and for the catalepsy data the KruskalWallis one-way ANOVA followed by Mann-Whitney $U$-test was used. Statistical evaluation of microdialysis data over time was performed by means of a two-way (treatment $\times$ time) ANOVA for repeated measures. To analyze difference between different treatments, we also measured the overall effects (AUC = area under curve), that is, interval 60-240 min for mPFC and 45-240 min for NAC. The overall effects were statistically evaluated by one-way ANOVA, followed by planned comparisons test. One-way ANOVA was also used to detect differences between baseline values. Statistical evaluation of the electrophysiology experiments were performed by paired $t$-test, and, for multiple group comparisons, one-way ANOVA followed by the post hoc 
Tukey's HSD test. In all statistical measures $p<0.05$ was considered significant. The statistical evaluations were performed by using Statistica version 8.0 (StatSoft).

\section{Drugs}

For in vivo experiments olanzapine was dissolved in a minimal amount of acetic acid with a $5.5 \%$ glucose solution added to volume and reboxetine was dissolved in saline $(0.9 \% \mathrm{NaCl})$ and administered by i.p. injections. Bicuculline methiodide, glycine and NMDA were purchased from Sigma-Aldrich, St Louis, MO and tetrodotoxin from Tocris, Bristol, UK. For the electrophysiological experiments, stock solutions of olanzapine and reboxetine (dissolved in dimethyl sulfoxide) were prepared. The possibility that peripheral pharmacokinetics, involving an interaction between reboxetine and low-dose olanzapine, could account for some of our findings seems unlikely, because olanzapine is metabolized by the enzyme CYP1A2, reboxetine is metabolized by an entirely different enzyme, CYP3A4.

\section{RESULTS}

Effects of Reboxetine, Olanzapine and the Combination of Reboxetine and Olanzapine on CAR Behavior

The overall effect showed a statistical significant suppression of CAR at $20 \mathrm{~min}\left(\chi^{2}(5)=28.71, p<0.001\right.$, Figure 1a) and $90 \mathrm{~min}\left(\chi^{2}(5)=27.24, p<0.001\right.$, Figure $\left.1 \mathrm{~b}, n=10\right)$, whereas at $240 \mathrm{~min}$ all animals were back to baseline performance. Compared with control, that is, saline + vehicle, olanzapine $1.25 \mathrm{mg} / \mathrm{kg}$ produced a small but significant suppression of CAR at $90 \mathrm{~min}(p<0.01)$, and olanzapine $2.5 \mathrm{mg} / \mathrm{kg}$ at both 20 and $90 \mathrm{~min}(p<0.01)$. Reboxetine $6 \mathrm{mg} / \mathrm{kg}$ had no effect on CAR behavior when given alone. However, the same dose of reboxetine enhanced the effect of a low dose of olanzapine $1.25 \mathrm{mg} /$ $\mathrm{kg}(20 \mathrm{~min} ; p<0.05)$, but not a high dose of olanzapine $2.5 \mathrm{mg} / \mathrm{kg}$.

The drug-induced suppression of CAR was accompanied by a concomitant decrease in intertrial crosses. There was a statistical significant overall effect for the intertrial crosses at $20 \mathrm{~min}\left(\chi^{2} \quad(5)=11.95, p<0.05\right)$ and $90 \mathrm{~min}\left(\chi^{2}\right.$ $(5)=13.25, p<0.05, n=10$, Table 1$)$. At $20 \mathrm{~min}$, there was a statistically significant decrease in intertrial crosses after saline + olanzapine $1.25 \mathrm{mg} / \mathrm{kg}$, reboxetine + olanzapine $1.25 \mathrm{mg} / \mathrm{kg}$ and reboxetine + olanzapine $2.5 \mathrm{mg} / \mathrm{kg}$, whereas at $90 \mathrm{~min}$ only reboxetine + olanzapine $2.5 \mathrm{mg} / \mathrm{kg}$ resulted in a statistically significant decrease. No escape failures were recorded at any time point for any of the treatments.

Effects of Reboxetine, Olanzapine and the Combination of Reboxetine and Olanzapine in the Catalepsy Test

Reboxetine $(6 \mathrm{mg} / \mathrm{kg})$, olanzapine $(1.25$ and $2.5 \mathrm{mg} / \mathrm{kg}$ ) and the combination of reboxetine and olanzapine were tested in the catalepsy test ( $30 \mathrm{~min}: H(5)=10.15, p=0.071 ; 60 \mathrm{~min}$ : $H(5)=11.35, \quad p<0.05 ; 120 \mathrm{~min}: H(5)=3.91, \quad p=0.56$; Table 2). Compared with control, that is, saline + vehicle, reboxetine $6 \mathrm{mg} / \mathrm{kg} \quad(p<0.001)$, as well as olanzapine $2.5 \mathrm{mg} / \mathrm{kg}(p<0.01)$ reached statistically significant level at $60 \mathrm{~min}$ (Figure 2). However, the median catalepsy scores
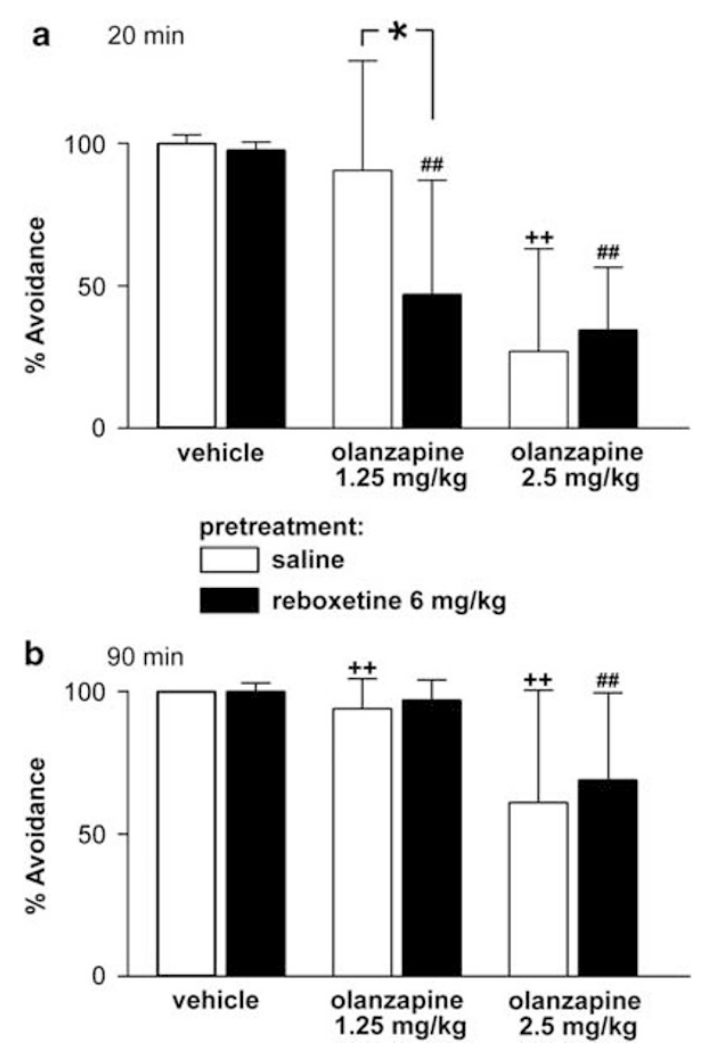

Figure I Reboxetine enhances the effect of a low, but not a high, dose of olanzapine on suppression of CAR. Effects on CAR behavior in rats at (a) $20 \mathrm{~min}$ and (b) $90 \mathrm{~min}$ after administration of vehicle, olanzapine 1.25 or olanzapine $2.5 \mathrm{mg} / \mathrm{kg}$ i.p. in combination with saline or reboxetine $6 \mathrm{mg} / \mathrm{kg}$ i.p. (reboxetine/saline was administered $30 \mathrm{~min}$ before vehicle/olanzapine). The results are presented as median (\% avoidance) \pm semi-interquartile range. Animals $(n=10)$ are serving as their own control in a change-over design $(\mathrm{Li}, 1964) .{ }^{+}+0<0.01$ vs saline + vehicle, ${ }^{\# \#} p<0.01$ vs reboxetine + vehicle, $* p<0.05$ saline + olanzapine vs reboxetine + olanzapine.

were all below 2, and in accordance with previous studies an animal was considered cataleptic only with a score $\geqslant 2$ (Wadenberg et al, 2001).

Effects of Reboxetine, Olanzapine and the Combination of Reboxetine and Olanzapine on Dopamine Output in the MPFC and the NAC

The mean \pm SEM basal extracellular dopamine levels in the $\mathrm{mPFC}$ and NAC were $0.32 \pm 0.03 \mathrm{fmol} / \mathrm{min}(n=26)$ and $2.62 \pm 0.22 \mathrm{fmol} / \mathrm{min}(n=23)$, respectively. No statistically significant differences between mean baseline concentrations of dopamine output were found between different treatments group within the same brain region studied. Control injections, that is, saline and vehicle, had no effect on dopamine output in any of the regions analyzed.

In the $\mathrm{mPFC}$, the maximal dopamine increase for reboxetine $6 \mathrm{mg} / \mathrm{kg}$ was $320 \%$ (at $60 \mathrm{~min}$ ), for olanzapine $1.25 \mathrm{mg} / \mathrm{kg} 102 \%$ (at $60 \mathrm{~min}$ ), for the combination of reboxetine $6 \mathrm{mg} / \mathrm{kg}$ and olanzapine $1.25 \mathrm{mg} / \mathrm{kg} 773 \%$ (at $60 \mathrm{~min}$ ) and for the control group (saline + vehicle injections) $16 \%$ (at $60 \mathrm{~min}$ ). Statistical evaluation for dopamine output in the mPFC (Figure 3a) revealed a significant treatment $\left(\mathrm{F}_{3,22}=13.89, p<0.001\right)$, time $\left(\mathrm{F}_{8,176}=30.47\right.$, $p<0.001$ ), as well as interaction (treatment $\times$ time) effect 
Table I Effects of Reboxetine (6 mg/kg i.p.) and Olanzapine (I.25, $2.5 \mathrm{mg} / \mathrm{kg}$ i.p.) on Intertrial Crosses in Rats

\begin{tabular}{llllll}
\hline Drugs (mg/kg) & & Pretest & $20 \mathrm{~min}$ & $90 \mathrm{~min}$ & $240 \mathrm{~min}$ \\
\hline Saline & tvehicle & $16.0 \pm 4.5$ & $13.0 \pm 4.0$ & $7.0 \pm 4.5$ & $12.5 \pm 7.0$ \\
Reboxetine (6) & +vehicle & $17.5 \pm 9.0$ & $7.5 \pm 5.5$ & $6.0 \pm 4.0$ & $8.0 \pm 5.0$ \\
Saline & tolanzapine (1.25) & $19.5 \pm 8.5$ & $7.0 \pm 3.5 *$ & $6.0 \pm 2.0$ & $7.5 \pm 4.0$ \\
Reboxetine (6) & tolanzapine (1.25) & $17.0 \pm 7.5$ & $5.0 \pm 5.5 *$ & $6.5 \pm 6.5$ & $8.0 \pm 4.0$ \\
Saline & tolanzapine (2.5) & $16.0 \pm 2.5$ & $5.0 \pm 5.5$ & $2.0 \pm 2.0$ & $6.0 \pm 3.5$ \\
Reboxetine (6) & tolanzapine (2.5) & $12.5 \pm 6.0$ & $3.0 \pm 5.5 *$ & $2.5 \pm 2.0 * *^{\#}$ & $3.5 \pm 3.5$ \\
\hline
\end{tabular}

The results are shown as medians \pm semi-interquartile range. Animals $(n=10)$ are serving as their own control in a change-over design ( $L i, 1964)$.

* $p<0.05, * * 0.05$ vs saline+vehicle; ${ }^{\#} p<0.05$ vs reboxetine+vehicle.

Table 2 Effects of Reboxetine (6 mg/kg i.p.) and Olanzapine ( 1.25 $2.5 \mathrm{mg} / \mathrm{kg}$ i.p.) on Catalepsy in Rats

\begin{tabular}{lllll}
\hline Drugs $(\mathrm{mg} / \mathrm{kg})$ & & $\begin{array}{c}\text { Score at } \\
30 \mathrm{~min}\end{array}$ & $\begin{array}{c}\text { Score at } \\
60 \mathrm{~min}\end{array}$ & $\begin{array}{c}\text { Score at } \\
120 \mathrm{~min}\end{array}$ \\
\hline Saline & +vehicle & $0.0 \pm 0.0$ & $0.0 \pm 0.0$ & $0.0 \pm 0.25$ \\
Reboxetine (6) & +vehicle & $0.5 \pm 0.5$ & $1.0 \pm 0.0$ & $0.5 \pm 1.0$ \\
Saline & +olanzapine (1.25) & $0.0 \pm 0.0$ & $0.0 \pm 0.25$ & $1.0 \pm 0.5$ \\
Reboxetine (6) & +olanzapine (1.25) & $0.0 \pm 0.0$ & $0.5 \pm 0.75$ & $1.0 \pm 1.0$ \\
Saline & +olanzapine (2.5) & $0.0 \pm 0.0$ & $1.0 \pm 0.5$ & $0.5 \pm 0.75$ \\
Reboxetine (6) & +olanzapine (2.5) & $0.0 \pm 0.0$ & $0.5 \pm 0.75$ & $1.0 \pm 0.5$ \\
\hline
\end{tabular}

The results are shown as medians \pm semi-interquartile range based on observations of eight animals per treatment group.

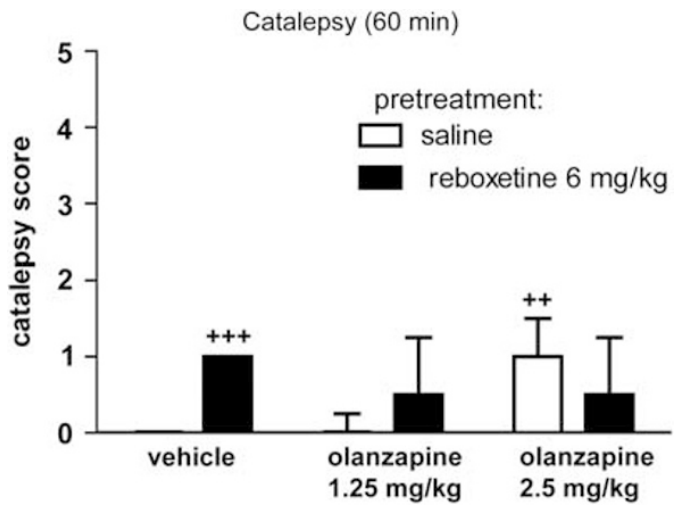

Figure 2 All treatments tested show very low propensity to induce catalepsy. Each bar represents the median catalepsy score \pm semiinterquartile range, measured at $60 \mathrm{~min}$, based on observations of eight animals per treatment group. ${ }^{++} p<0.01,{ }^{+++} p<0.001$ vs saline + vehicle.

$\left(\mathrm{F}_{24,176}=11.02, p<0.001\right)$. To assess the effects of the two drugs in combination, we analyzed the overall effect after injection of the second drug, AUC (60-240 min). The overall effect was statistically significant $\left(\mathrm{F}_{3,22}=14.21, p<0.001\right.$; Figure $3 b)$. Compared with control, that is, saline + vehicle, reboxetine, as well as the combination of reboxetine and olanzapine were significantly higher $(p<0.01-0.001)$. The combination of reboxetine and olanzapine was statistically higher than both reboxetine $(p<0.01)$ and olanzapine $(p<0.001)$, when given alone.
In the NAC, the maximal dopamine increase for reboxetine $6 \mathrm{mg} / \mathrm{kg}$ was $30 \%$ (at $225 \mathrm{~min}$ ), for olanzapine $1.25 \mathrm{mg} / \mathrm{kg} 172 \%$ (at $60 \mathrm{~min}$ ), for the combination of reboxetine $6 \mathrm{mg} / \mathrm{kg}$ and olanzapine $1.25 \mathrm{mg} / \mathrm{kg} \quad 202 \%$ (at $60 \mathrm{~min}$ ) and for the control group (saline + vehicle injections) $18 \%$ (at $30 \mathrm{~min}$ ). Statistical evaluation for dopamine output in the NAC (Figure 3c) revealed a significant treatment $\left(\mathrm{F}_{3,19}=13.24, \quad p<0.001\right)$, time $\left(\mathrm{F}_{16,304}=5.69, p<0.001\right)$, as well as interaction (treatment $\times$ time $)$ effect $\left(F_{48,304}=2.33, p<0.001\right)$. To assess the effects of the two drugs in combination, we analyzed the overall effect after injection of the second drug, AUC (45$240 \mathrm{~min})$. The overall effect was statistically significant $\left(\mathrm{F}_{3,19}=13.37, p<0.001\right.$; Figure $\left.3 \mathrm{~d}\right)$. Compared with control, that is, saline + vehicle, olanzapine, as well as the combination of reboxetine and olanzapine were significantly higher $(p<0.01-0.001)$. The combination of reboxetine and olanzapine was statistically higher than reboxetine $(p<0.001)$, when given alone.

\section{Effects of Reboxetine, Olanzapine and the Combination of Reboxetine and Olanzapine on Cortical NMDA- Induced Currents}

Intracellular voltage-clamp was used to record NMDAinduced currents in pyramidal cells of layer V and VI in the prelimbic region of the rat $\mathrm{mPFC}$. The characterization of pyramidal cells was performed according to criteria previously described (see above Arvanov et al, 1997; Konradsson et al, 2006).

The concentration-response curve for the effects of olanzapine, as well as other atypical APDs, on the NMDAinduced currents recorded has been shown to display an inverted U-shaped curve and the maximal effect of olanzapine were observed at $5 \mathrm{nM}$ (see Ninan et al, 2003). In this study, we examined a potential enhancement by reboxetine of a sub-maximal concentration of olanzapine, that is, $3 \mathrm{nM}$. First, reboxetine in various concentrations $(5,20,200$ and $1000 \mathrm{nM})$ was tested alone, and was generally found to produce very small effects on the NMDA-induced currents regardless of concentrations (data not shown). Plasma concentration in patients treated with reboxetine has been shown to be $660 \pm 346 \mathrm{nM}$ (mean $\pm \mathrm{SD}$; Öhman et al, 2001). Reboxetine shows an extensive (>97\%) binding to plasma proteins (Fleishaker 2000) and, as the amount of drug present in cerebrospinal fluid (CSF) tends to be equivalent at steady-state to the non-protein-bound 
a

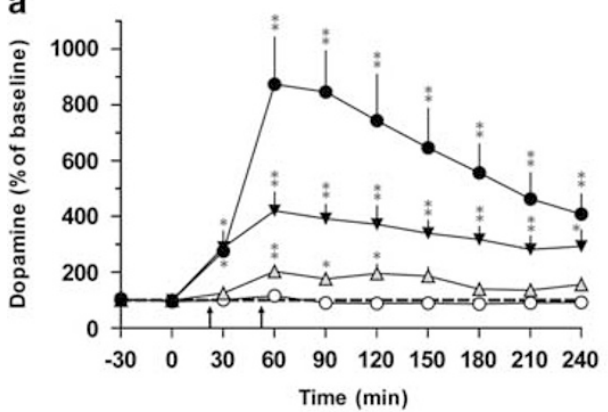

b

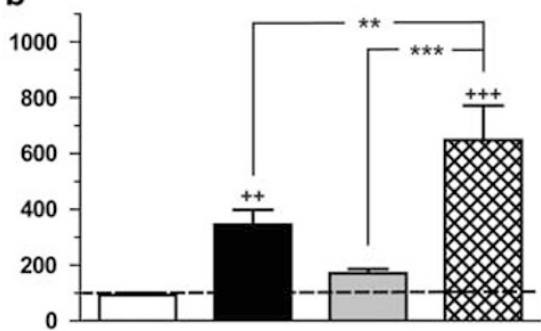

$\multimap-\square$ saline + vehicle

$\rightarrow-\square$ reboxetine $6 \mathrm{mg} / \mathrm{kg}$ + vehicle

$\triangle-\square$ saline + olanzapine $1.25 \mathrm{mg} / \mathrm{kg}$

$\rightarrow \square$ reboxetine $6 \mathrm{mg} / \mathrm{kg}$ + olanzapine $1.25 \mathrm{mg} / \mathrm{kg}$

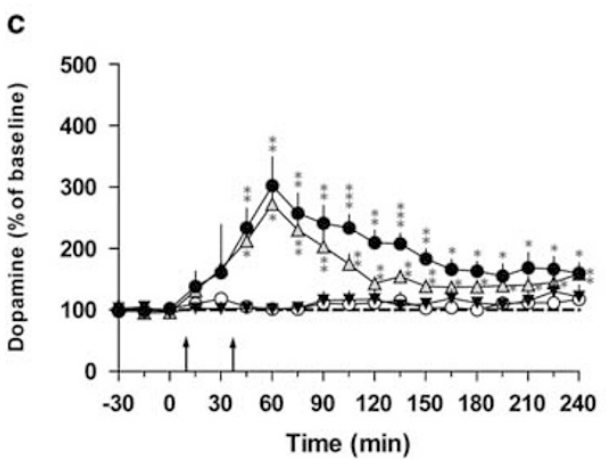

d

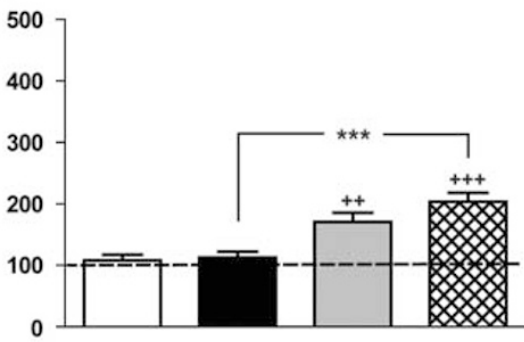

Figure 3 Reboxetine enhances the olanzapine-induced dopamine output in the mPFC, but not in the NAC. The effects of olanzapine $1.25 \mathrm{mg} / \mathrm{kg}$ i.p. administration on dopamine output in the $\operatorname{mPFC}(a, b)$ and $\operatorname{NAC}(c, d)$ respectively, in rats pretreated with saline or reboxetine $6 \mathrm{mg} / \mathrm{kg}$ (i.p.). Figures (a and c) show the effects on dopamine output over time in $\mathrm{MPFC}$ and NAC, respectively. Arrows indicate time of reboxetine/saline and olanzapine/vehicle injections. ${ }^{*} p<0.05$, $* * 0.01$, $* * * * 0.001$ compared with baseline. Figures (b and $d$ ) show the overall dopamine output (AUC), measured for 60-240 min (mPFC) and 45-240 min (NAC). The dotted line represents the baseline values (I00\%). The results are presented as mean \pm SEM. ${ }^{++} p<0.01$,

${ }^{++} p<0.00$ I compared with control group (saline/vehicle); $* * * 0.01$, $* * * *<0.00$ I between different treatments.

drug concentration in plasma, $20 \mathrm{nM}$ was chosen as a clinically relevant concentration.

There was a small but significant facilitation of the NMDA-induced currents by $20 \mathrm{nM}$ reboxetine $(117.7 \pm 4.2$ (mean \pm SEM), $n=7, t(6)=4.18, p<0.01$, Figure 4 ), whereas $3 \mathrm{nM}$ olanzapine did not reach statistical significance $(118.2 \pm 7.3, n=5, t(4)=2.49, p=0.07)$. The facilitating effect on NMDA-induced currents by the combination of reboxetine $20 \mathrm{nM}$ and olanzapine $3 \mathrm{nM}$ was highly significant $(170.0 \pm 6.0, n=5, t(4)=11.62, p<0.001)$. Group comparison $(\mathrm{F}$ (treatment: 2,14$)=26.3, p<0.001)$ revealed statistical significant differences between reboxetine $20 \mathrm{nM}$ and the combination of reboxetine $20 \mathrm{nM}$ and olanzapine $3 \mathrm{nM}$ $(p<0.001)$ and between olanzapine $3 \mathrm{nM}$ and the combination of reboxetine $20 \mathrm{nM}$ and olanzapine $3 \mathrm{nM}(p<0.001)$.

\section{DISCUSSION}

Our results show that the selective NET inhibitor reboxetine may significantly enhance the antipsychotic-like effect of a low, but not a high, dose of olanzapine, without inducing catalepsy. In principle, these data suggest the possibility of a dose reduction of olanzapine with maintained antipsychotic effect. The olanzapine-induced dopamine output in the mPFC, but not in the NAC, was significantly increased by

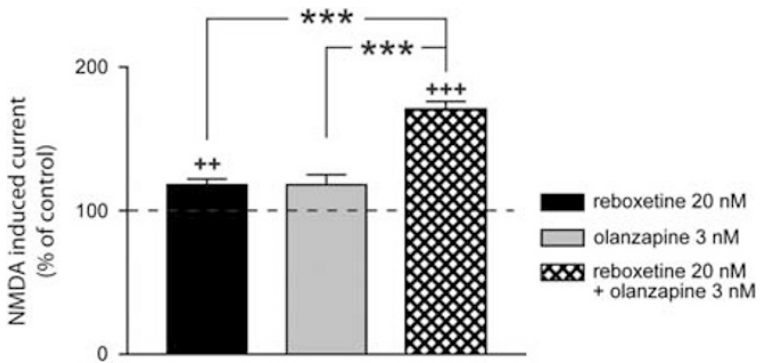

Figure 4 Reboxetine enhances the effect of a sub-maximal concentration of olanzapine on NMDA-induced currents in pyramidal cells. Bar representing the effects of reboxetine $20 \mathrm{nM}$, olanzapine $3 \mathrm{nM}$ and the combination of reboxetine $20 \mathrm{nM}$ and olanzapine $3 \mathrm{nM}$ on NMDA induced currents in pyramidal cells of the mPFC. The results are presented as mean \pm SEM. ${ }^{++} p<0.05, \quad{ }^{++} p<0.00$ I compared with baseline, ***** $p<0.00$ I between different treatments.

reboxetine. Finally, reboxetine was also shown to potentiate the effect of a low concentration of olanzapine on prefrontal glutamatergic NMDA receptor-mediated transmission. The preferential enhancement of cortical dopamine and NMDA receptor-mediated transmission suggest that addition of reboxetine to a sub-maximal dose of olanzapine may not only enhance the antipsychotic effect, but also ameliorate 
negative and depressive symptoms and cognitive impairment in schizophrenia (c.f. Introduction).

Reboxetine has previously been found to enhance the antipsychotic-like effect and cortical dopamine output of a low dose of the selective $\mathrm{D}_{2 / 3}$ antagonist raclopride, which by itself did not produce a sufficient antipsychotic effect (Linner et al, 2002). In this study, we found that the same dose of reboxetine also enhanced the antipsychotic-like effect and cortical dopamine output induced by a low dose of olanzapine, which also when given alone was far from producing a sufficient antipsychotic-like effect in the CAR model. The low doses of both raclopride and olanzapine used in these experiments produce approximately $60-65 \%$ occupancy of the $\mathrm{D}_{2}$ receptor (Marcus et al, 2005; Wadenberg et al, 2001). The doses needed for sufficient antipsychotic effect in the CAR model of both raclopride and olanzapine, when given alone, require approximately $75 \% \mathrm{D}_{2}$ receptor occupancy (Wadenberg et al, 2000, 2001). In schizophrenic patients treated with clozapine, the striatal dopamine receptor occupancy is rather low, that is, approximately 45\% (Kessler et al, 2006; Nordström et al, 1995), indicating that also other receptors than $D_{2}$ receptors contribute to its efficacy (see Svensson, 2003b). In schizophrenic patients treated with FGAs, the $\mathrm{D}_{2}$ receptor occupancy is approximately 70-80\% (Farde et al, 1988; Nordström et al, 1995), and a level similar to that of $\mathrm{D}_{2}$ receptor occupancy is also observed in patients treated with olanzapine (Tauscher et al, 1999; Zipursky et al, 2005). At high $\mathrm{D}_{2}$ receptor occupancy levels the risk of adverse side effects such as EPS and prolactin elevation are increased (Kapur et al, 2000). In addition, a high degree of $\mathrm{D}_{2}$ blockade per se may generate detrimental effects on both cognition and mood in healthy volunteers (Saeedi et al, 2006), as well as in schizophrenic patients (Carpenter Jr, 1996). Therefore, a lower $D_{2}$ receptor occupancy, which may be achieved by reducing the dose of olanzapine, may in principle even contribute to ameliorate cognitive and negative symptoms. The present data thus indicate that this goal may be attainable by adjunctive reboxetine treatment.

In similarity with reboxetine, the $\alpha_{2}$-adrenoceptor antagonist idazoxan has been shown to enhance the antipsychotic-like effects of raclopride and olanzapine, as well as haloperidol and risperidone, without inducing catalepsy. In addition, the prefrontal dopamine output induced by these APDs was markedly enhanced by idazoxan (Hertel et al, 1999; Marcus et al, 2009; Wadenberg et al, 2007). Furthermore, to a similar magnitude as that of clozapine, idazoxan enhanced the effects of both raclopride and risperidone on prefrontal NMDA receptor-mediated transmission, an effect that has been shown to be dopamine-dependent and executed through the dopamine $\mathrm{D}_{1}$ receptor (Chen and Yang, 2002; Marcus et al, 2005, 2009; Ninan and Wang, 2003). The increased prefrontal availability of catecholamines induced by adjunctive treatment with idazoxan is probably due to a co-release of dopamine and norepinephrine that is controlled by $\alpha_{2^{-}}$ adrenoceptors located on norepinephrine nerve terminals (Devoto et al, 2001).

NRIs have, in depressed patients, been suggested to improve drive and motivation, as well as cognitive impairment because of increased availability of cortical catecholamines (see Introduction). The increased availability of dopamine in the prefrontal cortex observed after administration of a selective NRI may largely be explained by the fact that dopamine has a high affinity for the NET, which thus contributes to clearance of dopamine from the extracellular space in the cortex (Carboni et al, 1990; Pozzi et al, 1994). Thus, after administration of a NET inhibitor, both norepinephrine and dopamine extracellular levels increase. The increased availability of dopamine in the prefrontal cortex may not only contribute to improve the effect on cognitive symptoms, but can probably also, in the presence of a $D_{2}$ antagonist, contribute to enhance the antipsychotic effect per se. Previous clinical studies show that low doses of L-dopa used as adjunct treatment to conventional APDs may enhance their therapeutic effect in schizophrenic patients (see Jaskiw and Popli, 2004), and experimental data reveal that adding low doses of L-dopa to raclopride not only caused a preferentially increased prefrontal cortical dopamine output, but also potentiated the antipsychotic-like effect of the $\mathrm{D}_{2 / 3}$ antagonist (Eltayb et al, 2005). Therefore, addition of drugs that are able to increase the availability of cortical monoamines, for example, reboxetine and idazoxan, to APDs may both enhance the antipsychotic effect, as well as improve negative or depressive symptoms and certain aspects of cognitive impairment.

Clinical studies using adjunctive treatment with NET inhibitors to APDs have show inconsistent results. Although reboxetine when added to a stable treatment with APDs, including both FGAs and SGAs, it was found to improve both positive and negative, as well as depressive symptoms in schizophrenic patients (Raedler et al, 2004), whereas reboxetine as add-on treatment to haloperidol did not cause any significant improvement (Schutz and Berk, 2001). In addition, adjunctive treatment with the NET inhibitor atomoxetine to schizophrenic patients treated with SGAs was found to activate certain brain areas related to working memory (Friedman et al, 2008). Interestingly, a recent study found no improvement of processing speed and accuracy by co-administration of reboxetine with olanzapine in schizophrenic patients (Poyurovsky et al, 2009), but the investigators concluded that a more comprehensive test battery, including tasks such as working memory, verbal memory and social cognition, might have been more useful. Needless to say, these clinical results are obtained from small pilot studies in patients maintained on effective doses of various APDs. However, this study suggests that the potential benefits of adjunctive NET inhibition would be obtained at reduced dosage of olanzapine rather than at standard dose levels. Significantly, quetiapine, with a structure similar to clozapine and olanzapine, has an active metabolite, norquetiapine, which is a potent NET inhibitor that has been identified and visualized in the primate brain (Nyberg et al, 2007). Thus, the recently shown antidepressant effect of quetiapine (Bandelow et al, 2010; Bauer et al, 2009; Cutler et al, 2009), as well as its utility in bipolar depression may be related to concomitant NET inhibition in combination with a low $\mathrm{D}_{2}$ occupancy (Kessler et al, 2006). Finally, clinical data indicate that adding a NET inhibitor such as reboxetine to olanzapine in the treatment of schizophrenia attenuates the olanzapine-induced weight gain (Poyurovsky et al, 2003, 2007). 
Consequently, further studies on NET inhibition as addon treatment to APDs in the treatment of schizophrenia seem warranted. Specifically, the present data suggest that the addition of a NET inhibitor to olanzapine treatment might allow for a dose reduction, yet with maintained and even broadened therapeutic effects and a concomitant reduction of dose-related side effects of olanzapine, such as EPS and weight gain. To our knowledge no clinical study using this approach has as yet been published.

\section{ACKNOWLEDGEMENTS}

This work was supported by the Swedish Research Council (grant no. 4747), the Karolinska Institutet, Torsten och Ragnar Söderbergs Stiftelser, Magn. Bergvalls Stiftelse, Åhlén-stiftelsen and the Lundbeck Foundation. The expert technical assistance of Mrs Ann-Chatrine Samuelsson is gratefully acknowledged. Reboxetine is widely used in over 60 countries, however, the FDA has declined the approval of reboxetine in the United States.

\section{DISCLOSURE}

The authors declare that there is no conflict of interest. Monica M Marcus, Anna Malmerfelt and Torgny $\mathrm{H}$ Svensson are employees at the Karolinska Institutet, Carl Björkholm is a $\mathrm{PhD}$ student at the Karolinska Institutet. Kent Jardemark is employee at the Karolinska Institutet and Pronexus Analytical AB.

\section{REFERENCES}

Abi-Dargham A, Mawlawi O, Lombardo I, Gil R, Martinez D, Huang $\mathrm{Y}$ et al (2002). Prefrontal dopamine d1 receptors and working memory in schizophrenia. J Neurosci 22: 3708-3719.

Abi-Dargham A, Moore H (2003). Prefrontal DA transmission at D1 receptors and the pathology of schizophrenia. Neuroscientist 9: 404-416.

Ahlenius S, Hillegaart V (1986). Involvement of extrapyramidal motor mechanisms in the suppression of locomotor activity by antipsychotic drugs: a comparison between the effects produced by pre- and post-synaptic inhibition of dopaminergic neurotransmission. Pharmacol Biochem Behav 24: 1409-1415.

Arnt J (1982). Pharmacological specificity of conditioned avoidance response inhibition in rats: inhibition by neuroleptics and correlation to dopamine receptor blockade. Acta Pharmacologica et Toxicologica 51: 321-329.

Arvanov VL, Liang X, Schwartz J, Grossman S, Wang RY (1997). Clozapine and haloperidol modulate N-methyl-D-aspartate- and non-N-methyl-D-aspartate receptor-mediated neurotransmission in rat prefrontal cortical neurons in vitro. J Pharmacol Exp Ther 283: 226-234.

Bandelow B, Chouinard G, Bobes J, Ahokas A, Eggens I, Liu S et al (2010). Extended-release quetiapine fumarate (quetiapine XR): a once-daily monotherapy effective in generalized anxiety disorder. Data from a randomized, double-blind, placeboand active-controlled study. Int J Neuropsychopharmacol 13: 305-320.

Bauer M, Pretorius HW, Constant EL, Earley WR, Szamosi J, Brecher M (2009). Extended-release quetiapine as adjunct to an antidepressant in patients with major depressive disorder: results of a randomized, placebo-controlled, double-blind study. J Clin Psychiatry 70: 540-549.
Beneyto M, Meador-Woodruff JH (2008). Lamina-specific abnormalities of NMDA receptor-associated postsynaptic protein transcripts in the prefrontal cortex in schizophrenia and bipolar disorder. Neuropsychopharmacology 33: 2175-2186.

Briand LA, Gritton H, Howe WM, Young DA, Sarter M (2007). Modulators in concert for cognition: modulator interactions in the prefrontal cortex. Prog Neurobiol 83: 69-91.

Carboni E, Tanda GL, Frau R, Di Chiara G (1990). Blockade of the noradrenaline carrier increases extracellular dopamine concentrations in the prefrontal cortex: evidence that dopamine is taken up in vivo by noradrenergic terminals. J Neurochem 55: 1067-1070.

Carpenter Jr WT (1996). The treatment of negative symptoms: pharmacological and methodological issues. $\mathrm{Br} J$ Psychiatry Suppl 29: 17-22.

Chamberlain SR, Muller U, Blackwell AD, Clark L, Robbins TW, Sahakian BJ (2006). Neurochemical modulation of response inhibition and probabilistic learning in humans. Science 311: 861-863.

Chen L, Yang CR (2002). Interaction of dopamine D1 and NMDA receptors mediates acute clozapine potentiation of glutamate EPSPs in rat prefrontal cortex. J Neurophysiol 87: 2324-2336.

Connors BW, Gutnick MJ (1990). Intrinsic firing patterns of diverse neocortical neurons. Trends Neurosci 13: 99-104.

Coyle JT, Tsai G, Goff D (2003). Converging evidence of NMDA receptor hypofunction in the pathophysiology of schizophrenia. Ann NY Acad Sci 1003: 318-327.

Cutler AJ, Montgomery SA, Feifel D, Lazarus A, Astrom M, Brecher $M$ (2009). Extended release quetiapine fumarate monotherapy in major depressive disorder: a placebo- and duloxetine-controlled study. J Clin Psychiatry 70: 526-539.

Davis JM, Chen N, Glick ID (2003). A meta-analysis of the efficacy of second-generation antipsychotics. Arch Gen Psychiatry 60: 553-564.

Devoto P, Flore G (2006). On the origin of cortical dopamine: is it a co-transmitter in noradrenergic neurons? Curr Neuropharmacol 4: 115-125.

Devoto P, Flore G, Pani L, Gessa GL (2001). Evidence for co-release of noradrenaline and dopamine from noradrenergic neurons in the cerebral cortex. Mol Psychiatry 6: 657-664.

Eltayb A, Wadenberg ML, Svensson TH (2005). Enhanced cortical dopamine output and antipsychotic-like effect of raclopride with adjunctive low-dose L-dopa. Biol Psychiatry 58: 337-343.

Farde L, Wiesel FA, Halldin C, Sedvall G (1988). Central D2dopamine receptor occupancy in schizophrenic patients treated with antipsychotic drugs. Arch Gen Psychiatry 45: 71-76.

Ferguson JM, Wesnes KA, Schwartz GE (2003). Reboxetine versus paroxetine versus placebo: effects on cognitive functioning in depressed patients. Int Clin Psychopharmacol 18: 9-14.

Fleishaker JC (2000). Clinical pharmacokinetics of reboxetine, a selective norepinephrine reuptake inhibitor for the treatment of patients with depression. Clin Pharmacokinet 39: 413-427.

Frånberg $\mathrm{O}$, Wiker $\mathrm{C}$, Marcus $\mathrm{MM}$, Konradsson $\AA$, Jardemark K, Schilström B et al (2008). Asenapine, a novel psychopharmacologic agent: preclinical evidence for clinical effects in schizophrenia. Psychopharmacol 196: 417-429.

Friedman JI, Carpenter D, Lu J, Fan J, Tang CY, White L et al (2008). A pilot study of adjunctive atomoxetine treatment to second-generation antipsychotics for cognitive impairment in schizophrenia. J Clin Psychopharmacol 28: 59-63.

Goldman-Rakic PS, Castner SA, Svensson TH, Siever LJ, Williams GV (2004). Targeting the dopamine $\mathrm{D}(1)$ receptor in schizophrenia: insights for cognitive dysfunction. Psychopharmacology (Berl) 174: 3-16.

Hennen J, Baldessarini RJ (2005). Suicidal risk during treatment with clozapine: a meta-analysis. Schizophr Res 73: 139-145. 
Hertel P, Fagerquist MV, Svensson TH (1999). Enhanced cortical dopamine output and antipsychotic-like effects of raclopride by alpha2 adrenoceptor blockade. Science 286: 105-107.

Jardemark K, Ninan I, Svensson TH, Wang RY (2002). Differential effects of atypical and typical antipsychotic drugs on NMDA-receptor-mediated neurotransmission in pyramidal cells of the rat medial prefrontla cortex. Nord J Psychiatry 56: 20.

Jaskiw GE, Popli AP (2004). A meta-analysis of the response to chronic L-dopa in patients with schizophrenia: therapeutic and heuristic implications. Psychopharmacology (Berl) 171: 365-374.

Kane J, Honigfeld G, Singer J, Meltzer H (1988). Clozapine for the treatment-resistant schizophrenic. A double-blind comparison with chlorpromazine. Arch Gen Psychiatry 45: 789-796.

Kapur S, Zipursky R, Jones C, Remington G, Houle S (2000). Relationship between dopamine $\mathrm{D}(2)$ occupancy, clinical response, and side effects: a double-blind PET study of firstepisode schizophrenia. Am J Psychiatry 157: 514-520.

Kasper S (1999). From symptoms to social functioning: differential effects of antidepressant therapy. Int Clin Psychopharmacol 14: S27-S31.

Kessler RM, Ansari MS, Riccardi P, Li R, Jayathilake K, Dawant B et al (2006). Occupancy of striatal and extrastriatal dopamine D2 receptors by clozapine and quetiapine. Neuropsychopharmacology 31: 1991-2001.

Konradsson $\AA$, Marcus MM, Hertel P, Svensson TH, Jardemark KE (2006). Inhibition of the glycine transporter GlyT-1 potentiates the effect of risperidone, but not clozapine, on glutamatergic transmission in the rat medial prefrontal cortex. Synapse 60: 102-108.

Lapiz MD, Morilak DA (2006). Noradrenergic modulation of cognitive function in rat medial prefrontal cortex as measured by attentional set shifting capability. Neuroscience 137: 1039-1049.

Leucht S, Corves C, Arbter D, Engel RR, Li C, Davis JM (2009). Second-generation versus first-generation antipsychotic drugs for schizophrenia: a meta-analysis. Lancet 373: 31-41.

Lewis SW, Barnes TR, Davies L, Murray RM, Dunn G, Hayhurst KP et al (2006). Randomized controlled trial of effect of prescription of clozapine versus other second-generation antipsychotic drugs in resistant schizophrenia. Schizophr Bull 32: 715-723.

Li CC (1964). Change-over design. In: Introduction to Experimental Statistics. McGraw-Hill Book Company: New York. pp 207-226.

Li XM, Perry KW, Wong DT, Bymaster FP (1998). Olanzapine increases in vivo dopamine and norepinephrine release in rat prefrontal cortex, nucleus accumbens and striatum. Psychopharmacology (Berl) 136: 153-161.

Linner L, Wiker C, Wadenberg ML, Schalling M, Svensson TH (2002). Noradrenaline reuptake inhibition enhances the antipsychotic-like effect of raclopride and potentiates D-2-blockageinduced dopamine release in the medial prefrontal cortex of the rat. Neuropsychopharmacology 27: 691-698.

Marcus MM, Jardemark KE, Wadenberg ML, Langlois X, Hertel P, Svensson TH (2005). Combined alpha2 and D2/3 receptor blockade enhances cortical glutamatergic transmission and reverses cognitive impairment in the rat. Int $J$ Neuropsychopharmacol 8: 315-327.

Marcus MM, Wiker C, Frånberg O, Konradsson-Geuken $\AA$, Langlois X, Jardemark $\mathrm{K}$ et al (2009). Adjunctive alpha2adrenoceptor blockade enhances the antipsychotic-like effect of risperidone and facilitates cortical dopaminergic and glutamatergic, NMDA receptor-mediated transmission. Int $J$ Neuropsychopharmacol 19: 1-13.

McCormick DA, Connors BW, Lighthall JW, Prince DA (1985). Comparative electrophysiology of pyramidal and sparsely spiny stellate neurons of the neocortex. J Neurophysiol 54: 782-806.
McEvoy JP, Lieberman JA, Stroup TS, Davis SM, Meltzer HY, Rosenheck RA et al (2006). Effectiveness of clozapine versus olanzapine, quetiapine, and risperidone in patients with chronic schizophrenia who did not respond to prior atypical antipsychotic treatment. Am J Psychiatry 163: 600-610.

Meltzer HY, Alphs L, Green AI, Altamura AC, Anand R, Bertoldi A et al (2003). Clozapine treatment for suicidality in schizophrenia: International Suicide Prevention Trial (InterSePT). Arch Gen Psychiatry 60: 82-91.

Meltzer HY, Huang M (2008). In vivo actions of atypical antipsychotic drug on serotonergic and dopaminergic systems. Prog Brain Res 172: 177-197.

Moghaddam B, Bunney BS (1990). Acute effects of typical and atypical antipsychotic drugs on the release of dopamine from prefrontal cortex, nucleus accumbens, and striatum of the rat: an in vivo microdialysis study. J Neurochem 54: 1755-1760.

Montgomery SA (1997). Reboxetine: additional benefits to the depressed patient. J Psychopharmacol 11: S9-15.

Ninan I, Jardemark KE, Wang RY (2003). Differential effects of atypical and typical antipsychotic drugs on N-methyl-Daspartate- and electrically evoked responses in the pyramidal cells of the rat medial prefrontal cortex. Synapse 48: 66-79.

Ninan I, Wang RY (2003). Modulation of the ability of clozapine to facilitate NMDA- and electrically evoked responses in pyramidal cells of the rat medial prefrontal cortex by dopamine: pharmacological evidence. Eur J Neurosci 17: 1306-1312.

Nomikos GG, Iurlo M, Andersson JL, Kimura K, Svensson TH (1994). Systemic administration of amperozide, a new atypical antipsychotic drug, preferentially increases dopamine release in the rat medial prefrontal cortex. Psychopharmacology (Berl) 115: 147-156.

Nordström AL, Farde L, Nyberg S, Karlsson P, Halldin C, Sedvall G (1995). D1, D2, and 5-HT2 receptor occupancy in relation to clozapine serum concentration: a PET study of schizophrenic patients. Am J Psychiatry 152: 1444-1449.

Nyberg S, Takano A, Grimm S, Gulyas B, McCarthy D, Lee C et al (2007). PET-measured D2, 5-HT2, and norepinephrine transporter (NET) occupancy by quetiapine and N-desalkyl-quetiapine in non-human primates. Eur Neuropsychopharmacol 17: S254.

Öhman D, Norlander B, Peterson C, Bengtsson F (2001). Bioanalysis of racemic reboxetine and its desethylated metabolite in a therapeutic drug monitoring setting using solid phase extraction and HPLC. Ther Drug Monit 23: 27-34.

Paxinos G, Watson C (1998). The Rat Brain in Stereotaxic Coordinates. 4th edn Academic Press: San Diego.

Poyurovsky M, Faragian S, Fuchs C, Pashinian A (2009). Effect of the selective norepinephrine reuptake inhibitor reboxetine on cognitive dysfunction in schizophrenia patients: an add-on, double-blind placebo-controlled study. Isr J Psychiatry Relat Sci 46: $213-220$.

Poyurovsky M, Fuchs C, Pashinian A, Levi A, Faragian S, Maayan $\mathrm{R}$ et al (2007). Attenuating effect of reboxetine on appetite and weight gain in olanzapine-treated schizophrenia patients: a double-blind placebo-controlled study. Psychopharmacology (Berl) 192: 441-448.

Poyurovsky M, Isaacs I, Fuchs C, Schneidman M, Faragian S, Weizman $\mathrm{R}$ et al (2003). Attenuation of olanzapine-induced weight gain with reboxetine in patients with schizophrenia: a double-blind, placebo-controlled study. Am J Psychiatry 160: 297-302.

Pozzi L, Invernizzi R, Cervo L, Vallebuona F, Samanin R (1994). Evidence that extracellular concentrations of dopamine are regulated by noradrenergic neurons in the frontal cortex of rats. J Neurochem 63: 195-200.

Raedler TJ, Jahn H, Arlt J, Kiefer F, Schick M, Naber D et al (2004). Adjunctive use of reboxetine in schizophrenia. Eur Psychiatry 19: $366-369$.

Saeedi H, Remington G, Christensen BK (2006). Impact of haloperidol, a dopamine D2 antagonist, on cognition and mood. Schizophr Res 85: 222-231. 
Salmi P, Samuelsson J, Ahlenius S (1994). A new computer-assisted two-way avoidance conditioning equipment for rats: behavioral and pharmacological validation. J Pharmacol Toxicol Methods 32: $155-159$.

Sara SJ, Devauges V (1989). Idazoxan, an alpha-2 antagonist, facilitates memory retrieval in the rat. Behavioral Neural Biol 51: 401-411.

Schotte A, Janssen PF, Gommeren W, Luyten WH, Van Gompel P, Lesage AS et al (1996). Risperidone compared with new and reference antipsychotic drugs: in vitro and in vivo receptor binding. Psychopharmacology (Berl) 124: 57-73.

Schatzberg AF (2000). New indications for antidepressants. J Clin Psychiatry 61: 9-17.

Schutz G, Berk M (2001). Reboxetine add on therapy to haloperidol in the treatment of schizophrenia: a preliminary double-blind randomized placebo-controlled study. Int Clin Psychopharmacol 16: $275-278$.

Shahid M, Walker GB, Zorn SH, Wong EH (2009). Asenapine: a novel psychopharmacologicagent with a unique human receptor signature. J Psychopharmacol 23: 65-73.

Stone JM, Morrison PD, Pilowsky LS (2007). Glutamate and dopamine dysregulation in schizophrenia-a synthesis and selective review. J Psychopharmacol 21: 440-452.

Svensson TH (2003a). Alpha-adrenoceptor modulation hypothesis of antipsychotic atypicality. Prog Neuropsychopharmacol Biol Psychiatry 27: 1145-1158.

Svensson TH (2003b). Preclinical effects of conventional and atypical antipsychotic drugs: defining the mechanisms of action. Clin Neurosci Res 3: 34-46.

Swartz MS, Stroup TS, McEvoy JP, Davis SM, Rosenheck RA, Keefe RS et al (2008). What CATIE found: results from the schizophrenia trial. Psychiatr Serv 59: 500-506.
Tauscher J, Kufferle B, Asenbaum S, Fischer P, Pezawas L, Barnas $C$ et al (1999). In vivo 123I IBZM SPECT imaging of striatal dopamine-2 receptor occupancy in schizophrenic patients treated with olanzapine in comparison to clozapine and haloperidol. Psychopharmacology (Berl) 141: 175-181.

Taylor DM, Duncan-McConnell D (2000). Refractory schizophrenia and atypical antipsychotics. J Psychopharmacol 14: 409-418.

Wadenberg ML, Hicks PB (1999). The conditioned avoidance response test re-evaluated: is it a sensitive test for the detection of potentially atypical antipsychotics? Neurosci Biobehav Rev 23: 851-862.

Wadenberg ML, Kapur S, Soliman A, Jones C, Vaccarino F (2000). Dopamine D2 receptor occupancy predicts catalepsy and the suppression of conditioned avoidance response behavior in rats. Psychopharmacology (Berl) 150: 422-429.

Wadenberg ML, Wiker C, Svensson TH (2007). Enhanced efficacy of both typical and atypical antipsychotic drugs by adjunctive alpha2 adrenoceptor blockade: experimental evidence. Int $J$ Neuropsychopharmacol 10: 191-202.

Wadenberg M-LG, Soliman A, VanderSpek SC, Kapur S (2001). Dopamine $\mathrm{d}(2)$ receptor occupancy is a common mechanism underlying animal models of antipsychotics and their clinical effects. Neuropsychopharmacology 25: 633-641.

Westerink BH, de Boer P, de Vries JB, Kruse CG, Long SK (1998). Antipsychotic drugs induce similar effects on the release of dopamine and noradrenaline in the medial prefrontal cortex of the rat brain. Eur J Pharmacol 361: 27-33.

Zipursky RB, Christensen BK, Daskalakis Z, Epstein I, Roy P, Furimsky I et al (2005). Treatment response to olanzapine and haloperidol and its association with dopamine D receptor occupancy in first-episode psychosis. Can J Psychiatry 50: $462-469$. 